\title{
EFFECT OF DIFFERENT DRYING METHODS ON SEED GERMINATION OF TWO PEPPER VARIETIES
}

\author{
Hasan Pinar 1,", Funga Ulrich ${ }^{1}$, Mahmut Kaplan ${ }^{2}$ \\ ${ }^{1}$ Erciyes University, Department of Horticulture-Kayseri, Turkey \\ ${ }^{2}$ Erciyes University, Department of Field Crops, Kayseri, Turkey
}

\section{Current Trends in \\ Natural Sciences}

\begin{abstract}
High seed germination is an important criteria in the seed industry, so the discovery of new processing processing methods that can improve percentage germination will be of great benefit for seed producers as well as for farmers. Seed germination tests of two pepper varieties (Bozok and pinar) that were dried using common (sun, shade, greenhouse) and novel (oven, microwave, liyofilization) drying methods were experimented. Two types of solid medium were used, one which was a mixture of peat and perlite (M1) and the other that contained only vermiculite (M2), a paper wet test in petridish (M3) was also performed, but was not replicated. There were no difference between both medium but a difference in viability in both varieties, Bozok was found to be more viable. Sun drying gave the highest emmergence rate $80 \%$ and $60 \%$ respectively in $M 2$ and $M 1$ for Bozok. Novel drying methods had no positive effect on seed germination.
\end{abstract}

Keywords: cultivars, driying methods, Pepper, seed germination

\section{INTRODUCTION}

Pepper (Capsicum ssp.) is a crop that has his center of diversification Brazil; its genus contains as much as 36 species (Eshbaugh, 2012). Among those existing species 5 are domesticated, 10 semidomesticated and 20 wild taxa (Costa et al, 2009). The crop is rich in vitamin A, B6, C, E, K and mineral such as manganese, potassium, copper and iron (Glodjinon et al, 2019). On the market pepper can be obtained in various forms; as fresh or dry fruit, powder and paste. In the world, pepper main producers include china with a production close to 16 million tones, next Mexico (2.3 million), Turkey (2.2 million) and Indonesia with 1.8 million (Penella and Angeles, 2018).

As it is the case for most plants, drying of seed is an important step to increase the quality and shelf life of pepper seeds, in industrial seed production it occurs after a certain process. Generally based on their physical characteristics (with, length and size) fruits are extracted through three methods; drying, wetting and fermentation (Yigit et al, 2018). With regard to pepper plant, seeds are extracted through mashing of fruits or by fermentation that can last up to 48 hours (McCormak, 2004). In an industrial drying facility, hot air is usually applied to belt dryers; it is a process that is quite expensive (Oztekin and Yelmen, 2010).

Seed germination is an important parameter in seed quality, in term of seed germination high percentage rate means the seed is of good quality. Usually the seed germination rate in plant is improved through the use of chemical that are harmful not only to seeds but also to the 
environment. The development of new technologies such as microwaves have proven to be good alternatives to the use of chemicals, microwave improves movement of water molecules and absorption in seeds (Rifna et al, 2019). In order to improve germination rate in pepper, many research have focused on direct sun drying and shade drying.

Alan (2007) conducted a research where he evaluated both pepper extraction and methods on germination rate. He discovered that there was no significant difference in germination percentage between sun and shade drying under dry extraction method, but seeds that went through wet extraction and dried under the shade showed significant high percentage germination. Moreover both natural methods gave better results than standart mechanical drying techniques used by seed companies.

The effect of drying methods on seed longevity of pepper was evaluated by adebisi and Rafiu(2016) exposed seeds to sun at average temperature of $30.8{ }^{\circ} \mathrm{C}$, passive drying (ventilated shade) $28.1{ }^{0} \mathrm{C}$ and oven drying at $35-400{ }^{\circ} \mathrm{C}$. Based on germination test he reported that passive drying was the more suitable method followed by sun then oven drying.

Microwave drying method was applied on other seeds than those of pepper. Radzevicius (2013), tested different vegetable seeds under three irradiation frequencies $(2.6,5.7$ and $9.3 \mathrm{Ghz})$ and periods. He reported that in carrot, seed germination increased when exposed to a $9.3 \mathrm{Ghz}$ frequency for five minute.

Plants such as lentil after they had been exposed to radiation treatments 450 and $750 \mathrm{~W}$ for various period of time showed that low power output at reduced exposure time could increase germination rate (Aladjadjiyan, 2010).

There are few information available and related to effect of novel drying techniques on seed germination of Capsicum spp, therefore the aim of this study is to evaluating the effect of some common and new drying methods on the germination of pepper seeds. The results that will be obtained may be used to improve the current drying methods used by companies and some local farmers.

\section{MATERIALS AND METHODS}

This rearch was carried out in Erciyes university, Department of Horticulture. Two pepper genotypes were exposed to different drying methods and later, realized germination tests was done in order to evaluate their effectiveness.

\subsection{Drying methods}

A microwave oven obtained from the Arçelik company, it was used in other to perform convective hot air and microwave drying. The appliance had a frequency of $2.465 \mathrm{MHZ}$ that correspond to 900 Watt and a heating capacity of 2800 C. Pepper was set consecutively in both section of the of the appliance, for microwave drying, power was set at $300 \mathrm{~W}$ for 3 minutes, meanwhile for convective drying temperature was set at $600 \mathrm{C}$ for 90 minutes. For direct sun, shade and green house drying, samples were laid on paper of a dimension of $50 \mathrm{~cm} \mathrm{x} 50 \mathrm{~cm}$ and allowed to dry for 8 hours at a temperature varying between $28-380 \mathrm{C}$ and relative humiity estimated at $64.7 \%$. Freeze drying was done with a freeze dryer purchased in Germany (Christ ALPHA 2-4 LSC plus ). Pepper fruit samples were first weighed and preserved at $-800 \mathrm{C}$ for 24 hours. Later in the freeze dryer, they were exposed to a pressure equivalent to $7.5 \times 10-6$ Torr $(1$ Torr $=10-5$ bar $)$ and a condensor temperature set at $-43.150 \mathrm{C}$. When the frozen samples were about to reach sublimation point, temperature was brought to $100{ }^{\circ} \mathrm{C}$ the progressively raised up to $500{ }^{\circ} \mathrm{C}$. 


\section{Current Trends in Natural Sciences}

Vol. 10, Issue 19, pp. 129-133, 2021

https://doi.org/10.47068/ctns.2021.v10i19.017

Current Trends in Natural Sciences (on-line)

ISSN: 2284-953X

Current Trends in Natural Sciences (CD-Rom)

ISSN: 2284-9521

ISSN-L: 2284-9521

ISSN-L: 2284-9521

\subsection{Germination test}

Germination was carried out in three different medium; peat moss + perlite, vermiculite and petridish media. In the first test, a mixture of perlite and torf at a proportion of 1:2 was used and laid in 45 cells seedling viols. İn vermiculite contained in viols seeds were sown at a rate of 3 seeds per cells. For all treatments a total of 19 petridish was used for both genotypes. Each petridish contained 20 seeds underlined by two layers of filter paper and another one which was laid above the seeds. A total of 2 pepper cultivars were experimented. Each medium was supplemented at planting once with potassium sulfate $16 \mathrm{~g} / \mathrm{L}$. In the paper wet test $80 \times 10-3 / \mathrm{L} \mathrm{GA}_{3}$ was used to improve germination rate. Folowing planting, watering, plant emmergence and germination record keeping was performed every two days. The SAS online student program was used to carry out analyses of variance, and the duncan test in order to evaluate the difference among treatment.

\section{RESULTS AND DISCUSSIONS}

Bozok and pinar cultivars were both exposed to simultaneous drying treatments, in december at the same date they were sown in a mixed medium containing peat and perlite, and in another medium containing only vermiculite. Torf + perlite based test revealed the highest percentage emmergence for Bozok cultivar when exposed to sun drying (60\%). Shade drying produced very poor results, $(<40 \%)$ meanwhile both microwave $(300 \mathrm{~W})$ and convective drying $\left(600{ }^{0} \mathrm{C}\right)$ did not allow emmergence at all. Pinar cultivar for all treatments gave no response except for sun dry treatment which was about $6 \%$.

In the vermiculite based test, Bozok still recorded high emmergence rate with sun drying $(80 \%)$ and green house drying treatment $(53 \%)$, while in other treatments gave zero response. Pinar cultivar again performed poorly in all treatments; $6 \%$ emmergence in both shade and drying in greenhouse, then no response for microwave and freeze drying (liyofilization).

The paper wet test in petridishes gave good germination percentage $(90 \%)$ for bozok genotype under sun dry method and a null result for pinar. However, pinar $(65 \%)$ when dried under shade showed a better result than bozok $(35 \%)$ under the same condition.

Table 1. Seed Germination Test Results

\begin{tabular}{|c|c|c|c|c|c|}
\hline Varieties & & Treatments & $\begin{array}{l}\text { Sown } \\
\text { Seeds }\end{array}$ & $\begin{array}{l}\text { Germinated } \\
\text { Seeds }\end{array}$ & $\begin{array}{l}\text { Seed Germination } \\
\text { Ratio }(\%)\end{array}$ \\
\hline \multirow[b]{13}{*}{ Pinar } & \multirow[b]{5}{*}{ Medium 1} & sun & 15 & 1 & 6.67 \\
\hline & & shade & 15 & - & - \\
\hline & & greenhouse & 15 & - & - \\
\hline & & UV & & - & - \\
\hline & & F.D & & - & - \\
\hline & \multirow[b]{5}{*}{ Medium 2} & sun & 15 & - & - \\
\hline & & shade & 15 & 1 & 6.67 \\
\hline & & greenhouse & 15 & 1 & 6.67 \\
\hline & & UV & & - & - \\
\hline & & F.D & & - & - \\
\hline & \multirow[b]{3}{*}{ Medium 3} & sun & 20 & - & - \\
\hline & & shade & 20 & 13 & 65.00 \\
\hline & & greenhouse & 20 & - & - \\
\hline
\end{tabular}




\section{Current Trends in Natural Sciences}

Vol. 10, Issue 19, pp. 129-133, 2021

https://doi.org/10.47068/ctns.2021.v10i19.017

Current Trends in Natural Sciences (on-line)

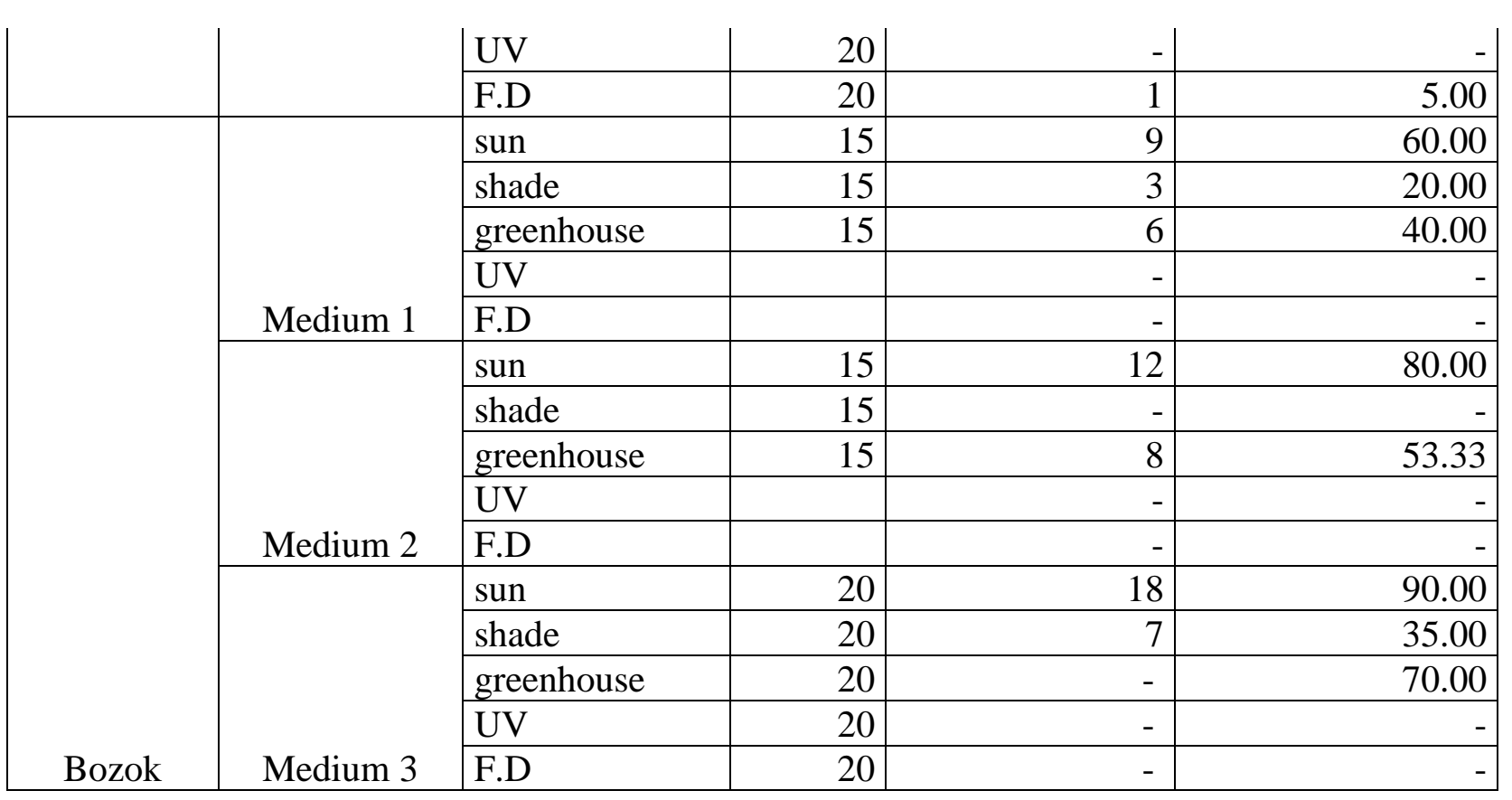

UV: Microwave(convective drying)

FD: Mreeze drying (liyofilization)

Medium 1= Peat + Perlite (1:2 ratio)
Medium 2= Vermiculite

Medium 3= Paper wet test

Table 2. Mean value of experimented varieties and treatments.

\begin{tabular}{|c|c|c|c|c|c|c|c|c|}
\cline { 2 - 9 } \multicolumn{1}{c|}{} & \multicolumn{2}{c|}{ var } & \multicolumn{9}{c|}{ treatments } \\
\cline { 2 - 9 } \multicolumn{1}{c|}{} & Bozok & Pinar & Sun & Greenhouse & Shade & Convective(uv) & F.D & microwave \\
\hline Mean & $0.66^{\mathrm{a}}$ & $0.05^{\mathrm{b}}$ & $1^{\mathrm{a}}$ & $0.75^{\mathrm{a}}$ & $0.35^{\mathrm{b}}$ & $0.05^{\mathrm{bc}}$ & $0^{\mathrm{c}}$ & $0^{\mathrm{c}}$ \\
\hline
\end{tabular}

Means with the same letters are not significant different $(\mathrm{P}<0.05)$. UV $=$ Convective drying, $\mathrm{F} . \mathrm{D}=$ freeze drying.

\section{Variety performance}

Bozok and Pinar are both varieties used to examine the effect of different drying methods. Treatments did not have similar effect on both varieties just because they were found different $(\mathrm{P}<0.05)$. differences in this case can be explained by the poor viability of pinar variety compared to Bozok. The germination test in petridish is there to prove results obtained in the other two tests carried out; the results recorded by pinar are similar for all treatments except for shade drying which paper test results could not be reflected.

The poor germination and emmergence rate may be caused by the fast deterioration of seeds. Adebisis and Rafiu (2016) reported a significant decrease in seed viability of different cayenne species from 4 months after storage. He stated that the rapid aging of seeds caused by the storage conditions could have been the cause of the low seed germimination percentage.

\section{Effect of drying treatments on seed germination}

Sun and greenhouse drying techniques came out to be the most suitable drying methods that do not affect poorly seed germination in pepper. According to analysis of variance, there was no significant difference between both techniques. However these results are not similar to those of 
Alan (2007) and Adebisis and Rafiu (2016) who reported high germination rate under shade drying treatment.

Novel drying techniques such as convection, freeze and microwave driying have not been proven effective in this case, meanwhile their effectiveness in improving product quality has been praised by many authors such as Rifna et al (2019) and Sanchez et al (2020). Although these methods have succeeded to improve seed germination and emmergence in some crops and have not been effective in others, it is now obvious that pepper with regard to germination is among those crops that do not respond positively to novel drying methods.

\section{CONCLUSIONS}

Four drying methods were evaluated based on on their effect on seed germination. Two pepper varieties bozok and pinar were used as sample, they all have been subjected to the same treatments. Among the various treatment applied sun and green house drying were found to be the most appropriate drying techniques to use in order to expect good germination rate. Novel drying techniques such as convective, freeze (lyophilisation) and microwave drying had negative impact on germination.

\section{REFERENCES}

Eshbaugh, W.H. (2012). The taxonomy of the Genius Capsicum. ResearchGate. (PDF) The taxonomy of the genus capsicum (researchgate.net)

Costa, L.V., Ricardo, L., Maria, T.G. L., Antenor, F.F., Willian, S.B., Silfran, R.M.A. (2008). Cross compatibility of domesticated hot pepper and cultivated sweet pepper. Crop Breeding and Applied Biotechnology 9, 37-44, 2009.Brazilian Society of Plant Breeding. DOI: 10.12702/1984-7033.v09n01a06

Glodjinon, N.M., Pacôme, A.N., Kifouli, A., Kamal, G., Sonangnon, HSK., Brice, MO., Hama, C., Noel, S.T., Marcelin, C.F., Fatiou, T., Lamine, B.M., Aly, S., Farid, B.M., (2019). The technical production, storage and conservation routes of chilli peppers (Capsicum spp.) Produced in benin and constraints impeding the development of the sector. Journal of Animal \& Plant Sciences, 42 (3), 7279-7295. https://doi.org/10.35759/JAnmP1Sci.v42-3.1

Penella, C., Angeles, C. (2018). Pepper crop under climate change: Grafting as an environmental friendly strategy. researchGate. http://www.intechopen.com/books/climate-resilient-agriculturestrategies-and-perspectives

Üzeyir Yiğit, Z.M., G.H., Şeyma, S., Ahmet, B. (2018). Sebze tohumlarinda uygulanan tohum işleme teknikleri [Seed processing techniques applied to vegetable seeds]. TÜRKTOB.

McCormack, J.F. (2010). Principles and practices of seed harvesting, processing, and storage: an organic seed production manual for seed growers in the Mid-Atlantic and Southern U.S. https://www.researchgate.net/publication/216379642

Oztekin, Z., Bekir, Y. (2010). Red chili pepper drying by farm scale hot house. Journal of agricultural machinery science, 63-70.

Rifna, E.J., Ramanan, K.R., Mahendran, R. (2019). Trends in Food Science \& Technology. Science direct. www.elsevier.com/locate/tifs

Alan, O., Benian, E. (2007). Biberde (capsicum annuum 1.) Tohum ayirma ve kurutma yöntemlerinin tohum kalitesi üzerine etkisi [The effect of seed separation and drying methods on seed quality in pepper (Capsicum annuum 1.)]. Anadolu, J. of AARI.

Adebisis, M.A., Rafiu, A.M.A. (2016). Storage Life of Cayenne Pepper(Capsicum frutescens) Seeds Following Three Drying Method. https://www.jstor.org/stable/26625370

Radzevičius, A., Sandra, S., Mindaugas, D., Rimantas, S., Rasa, K., Česlovas, B., Pavelas, D. (2013). The effect of strong microwave electric field radiation on: (1) vegetable seed germination and seedling growth rate. Zemdirbyste-Agriculture, 100(2), 179-184.

Aladjadjiyan, A. (2010). Influence of stationary magnetic field on lentil seeds. International agrophysics, 321-324.

Sánchez, A.C., Leontina, L.I., Marina, CL., Abdolreza, K., Klaudia, M., Ángel, A.C.B., Adam, F. (2020). Comparison of traditional and novel drying techniques and its effect on quality of fruits, vegetables and aromatic herbs. MPDI. 